Original Research Paper

\title{
Isolation, Purification, and Toxicity Test of Bacillus thuringiensis from Cows Cage Soil Againts Drosophila melanogaster
}

\author{
Syamsul Bahri ${ }^{{ }^{*}}$, Lalu Zulkifli ${ }^{1}$, Dewa Ayu Citra Rasmi ${ }^{1}$, Prapti Sedijani ${ }^{1}$ \\ ${ }^{1}$ Biology Education Study Program, Faculty of Teacher Training and Education, University of Mataram, \\ Indonesia
}

\begin{abstract}
Article History
Received : December 02 $2^{\text {th }}, 2021$

Revised : December $10^{\text {th }}, 2021$

Accepted : December $23^{\text {th }}, 2021$

Published : December $31^{\text {th }}, 2021$

*Corresponding Author:

Syamsul Bahri,

Biology Education Study

Program, Faculty of Teacher

Training and Education,

University of Mataram, Indonesia

Email:

syamsulsalihu@gmail.com
\end{abstract}

\begin{abstract}
Bacillus thuringiensis is one of the bacteriae species that be able to kill insects. The latest research showed that the cell plasm of this bacteria contains crystalline protein with natural insectisides properties. Therefore the insecticidal effect of this species on insects which is decreasing cultivation plant production is interest to be examined. One of the insect species that are well-known causes of loss of farm production in fruit flies (Drosophila melanogaster). Therefore this research is designed to isolate, purify, and thenassess Bacillus thuringiensis toxicity against Drosophila melanogaster as animal treatment. Bacillus thuringiensis was successfully isolated from soil of cows cage by using Lauria Bertani medium contain 0,25 M buffer solution Acetic, $\mathrm{pH}$ 6.8. The result shows that Bacillus thuringiensis isolate is a gram-positive bacteria. Position of endospore is located between the middle and the end of the cell (subterminal spore). Toxicity test was conducted by mixing $0.5 \mathrm{~g} / \mathrm{L}, 1 \mathrm{~g} / \mathrm{L}, 2 \mathrm{~g} / \mathrm{L}, 4 \mathrm{~g} / \mathrm{L}$ of pure Bacillus thuringiensis isolate into Drosophila melanogaster medium. The treatments effect were monitored for 15 consecutive days. Toxicity test shows that the treatment has no significant effect on the treated animal mortality. This result shows that crystal-producing Bacillus thuringiensis strain isolated from cows cage soil do not have insecticidal properties for Drosophila melanogaster. It is concluded that Drosophila melanogaster is a non-target species of Bacillus thuringiensis.
\end{abstract}

Keywords: Bacillus thuringiensis, Drosophila melanogaster, Toxicity test

\section{Pendahuluan}

Bacillus thuringiensis adalah salah satu spesies bakteri yang diketahui memiliki kemampuan membunuh serangga yang yang tergolong ke dalam ordo Lepidoptera, Diptera, Coleoptera dan Hymenoptera, serta nematoda (Schnep, et al., 1998; Wei, et al. 2003). Penelitian yang dilakukan oleh Crickmore et al. (1998) menunjukkan bahwa bakteri ini bekerja sebagai insektisida alami dengan menggunakan protein kristal yang terkandung di dalam selnya. Dengan demikian bakteri ini menarik untuk diteliti lebih lanjut untuk mengetahui efektifitasnya terhadap spesies-spesies serangga hama seperti Lalat buah (Diptera: Tephritidae) Drosophila melanogaster yang mengganggu dan menurunkan produksi tanaman-tanaman budidaya. Lalat buah (Diptera: Tephritidae) termasuk salah satu hama potensial yang sangat merugikan produksi sayuran dan buah-buahan, baik dari sisi kualitas maupun kuantitas
(Copeland et al., 2006). Jenis hama ini menjadi hama utama pada buah-buahan di seluruh dunia (Vargas et al., 2005), termasuk di Indonesia (Siwi et al, 2006). Berdasarkan PP Nomor 14 Tahun 2002, lalat buah termasuk Organisme Pengganggu Tumbuhan Karantina (OPTK) yang ditetapkan oleh Kementerian Pertanian untuk dicegah masuknya ke dalam dan tersebarnya di wilayah Negara Republik Indonesia (Suwanda, 2005).

Usaha yang diupayakan untuk mengatasi serangan lalat buah diantaranya dengan umpan protein (BAT), teknik jantan mandul (SIT), atraktan, pemanfaatan musuh alami, dan insektisida. Penggunaan insektisida kimia menjadi salah satu teknik pengendalian hama yang sangat berbahaya karena residunya akan mencemari lingkungan. Disamping itu, insektisida kimia menyisakan residu racun pada tanaman yang bila kemudian dikonsumsi oleh manusia dapat mengganggu kesehatan, atau bahkan mematikan. Oleh sebab itu penelitian- 
penelitian yang terkait dengan penggantian insektisida kimia yang sangat berbahya ini dengan insektisida alami penting dilakukan. Bahan insektisida alami dapat didaur ulang sehingga ramah lingkungan dan tidak menyebabkan dampak negatif jika diaplikasikan dalam dosis banyak seperti terjadinya resistensi hama ataupun toksik pada hasil pertanian (WHO, 1990; Hayes et al, 2006; Zheng, et al, 2016).

Penemuan, penggunaan, dan pengembangan insektisida alami dalam upaya pengendalian hama tanaman budidaya penting untuk segera dilakukan. Hal tersebut disebabkan karena insektisida kimia berpotensi merusak lingkungan dan mengganggu kesehatan konsumen. Hasil-hasil penelitian tentang penemuan dan pengembangan insektisida alami sangat penting untuk segera tersedia dalam upaya menekan atau bahkan menghindari penggunaan insektisida kimiawi. Penelitian ini dilakukan selama 8 bulan (Mei s/d Desember 2016) dengan tujuan mengisolasi, memurnikan, dan menguji toksisitas Bacillus thuringiensis terhadap lalat buah. Hasil dari penelitian ini diharapkan dapat digunakan untuk mengetahui teknik isolasi dan purifikasi Bacillus thuringiensis, serta kemungkinan pengembangannya sebagai insektisida alami dalam upaya pengedalian hama Lalat buah.

\section{Bahan dan Metode}

Penelitian ini dilaksanakan pada bulan Mei sampai Desember 2016. Pengambilan sampel tanah dilakukan di kandang sapi milik warga yang ada di daerah Sandik, Lombok Barat. Identifikasi, Isolasi dan Purifikasi serta Pengecatan Gram dan Spora dilakukan di Laboratorium Mikrobiologi FKIP Universitas Mataram, sedangkan uji toksisitas dilakukan di Ruang Kultur Drosophila FKIP Universitas Mataram.

Adapun alat yang dibutuhkan pada penelitian ini adalah ose, tabung reaksi, tabung Erlenmeyer, kertas jagung, karet gelang, autoclave, laminar air flow, kaca preparat, petridish, mikro pipet, mikroskop, vortex, inkubator, $\mathrm{pH}$ meter, kamera, botol kultur Drosophila, Syring $50 \mathrm{ml}$. Bahan yang digunakan diantaranya sampel tanah sebanyak 10 gram, media nutrient agar, trypton (oxoid), yeast extract (oxoid), $\mathrm{NaCl}$, larutan asam asetat, larutan
$\mathrm{NaOH}$, iodin, safranin, kristal violet, aquadest, malachite green, spiritus, pisang, gula merah, agar-agar, dan ragi roti.

\section{Koleksi Sampel sumber Bacillus thuringiensis}

Diambil sebanyak 100 gram sampel tanah dengan kedalaman $20 \mathrm{~cm}$ dari atas permukaan tanah yang berada di daerah kandang sapi yang berada di Sandik. Kemudian dimasukkan kedalam kantong plastik berukuran 250 gram. Sampel tanah yang sudah ada diberikan label yang berisi keterangan tentang tanggal pengambilan dan lokasi pengambilan. Sebelum digunakan untuk isolasi bakteri dan pemurnian, sampel tanah tersebut disimpan dalam ruang dingin yang bersuhu $4^{0} \mathrm{C}$.

\section{Isolasi dan Pemurnian Bacillus thuringiensis}

Media yang digunakan dalam percobaan ini adalah Nutrient Agar (NA) modifikasi yang diperkaya ekstrak yeast $0,3 \%(\mathrm{~b} / \mathrm{v})$ sesuai metode (Brotonegoro et al., 1997) yang berfungsi sebagai media isolasi, pemurnian dan pemeliharaan .

\section{Induksi sporulasi}

Untuk menginduksi terjadinya sporulasi maka kultur murni Bacillus thuringiensis di pelihara pada media yang mengandung tryptose. Dalam 2-5 hari Bacillus thuringiensis akan bersporulasi dalam media ini dengan pengocokan pada suhu $30^{\circ} \mathrm{C}$

\section{Uji toksisitas}

Koloni Bacillus thuringiensis murni yang telah dikultur pada medium yang mengandung tryptose hingga mengalami sporulasi dicampur homogen dengan medium lalat buah hingga diperoleh 5 konsentrasi perlakuan yaitu $0,5 \mathrm{~g} / \mathrm{L}$, $1 \mathrm{~g} / \mathrm{L}, 2 \mathrm{~g} / \mathrm{L}$, dan $4 \mathrm{~g} / \mathrm{L}$. Medium lalat buah terbuat dari campuran bubur pisang ambon, gula merah, tepung agar-agar, dan gist yang dimasak hingga mendidih selama 30 menit. Sebanyak 20 ekor imago Drosophila melanogaster dimasukkan ke dalam setiap botol medium untuk selanjutnya diamati tingkat mortalitasnya.

\section{Hasil dan Pembahasan}

Hasil yang diperoleh dari percobaan ini antara lain sbb; 
Tabel 1. Hasil Pengamatan Morfologi Bakteri pada Medium NA

\begin{tabular}{|l|l|}
\hline Gambar & Keterangan \\
\hline Pengenceran $10^{-1}$ & \\
& \\
& \\
&
\end{tabular}

Tabel 2. Hasil Pengamatan Morfologi Bakteri pada Campuran Medium NA dengan LB Dapar Asetat

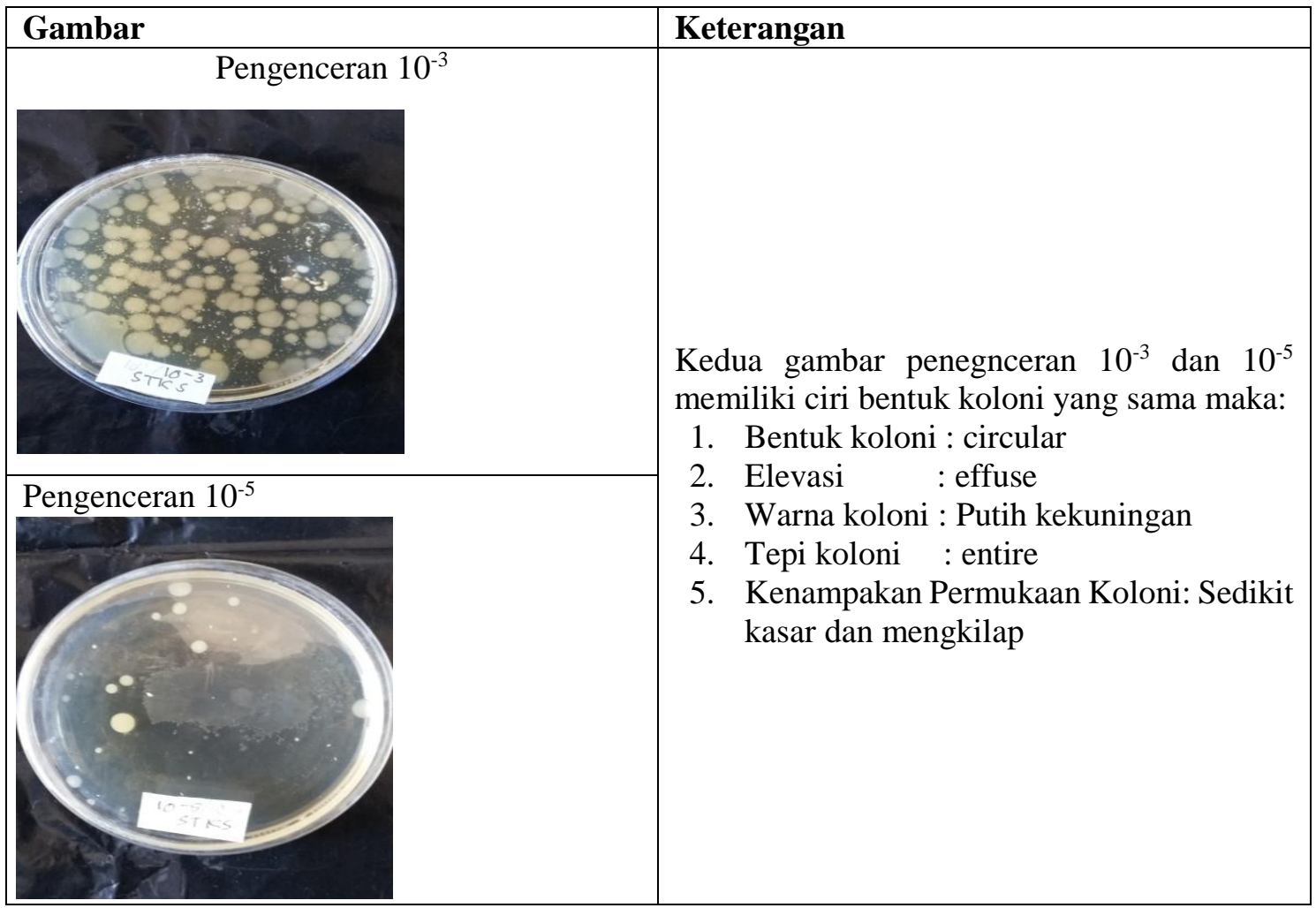


Tabel 3. Hasil Pengamatan Bakteri pada Medium LB Agar Miring

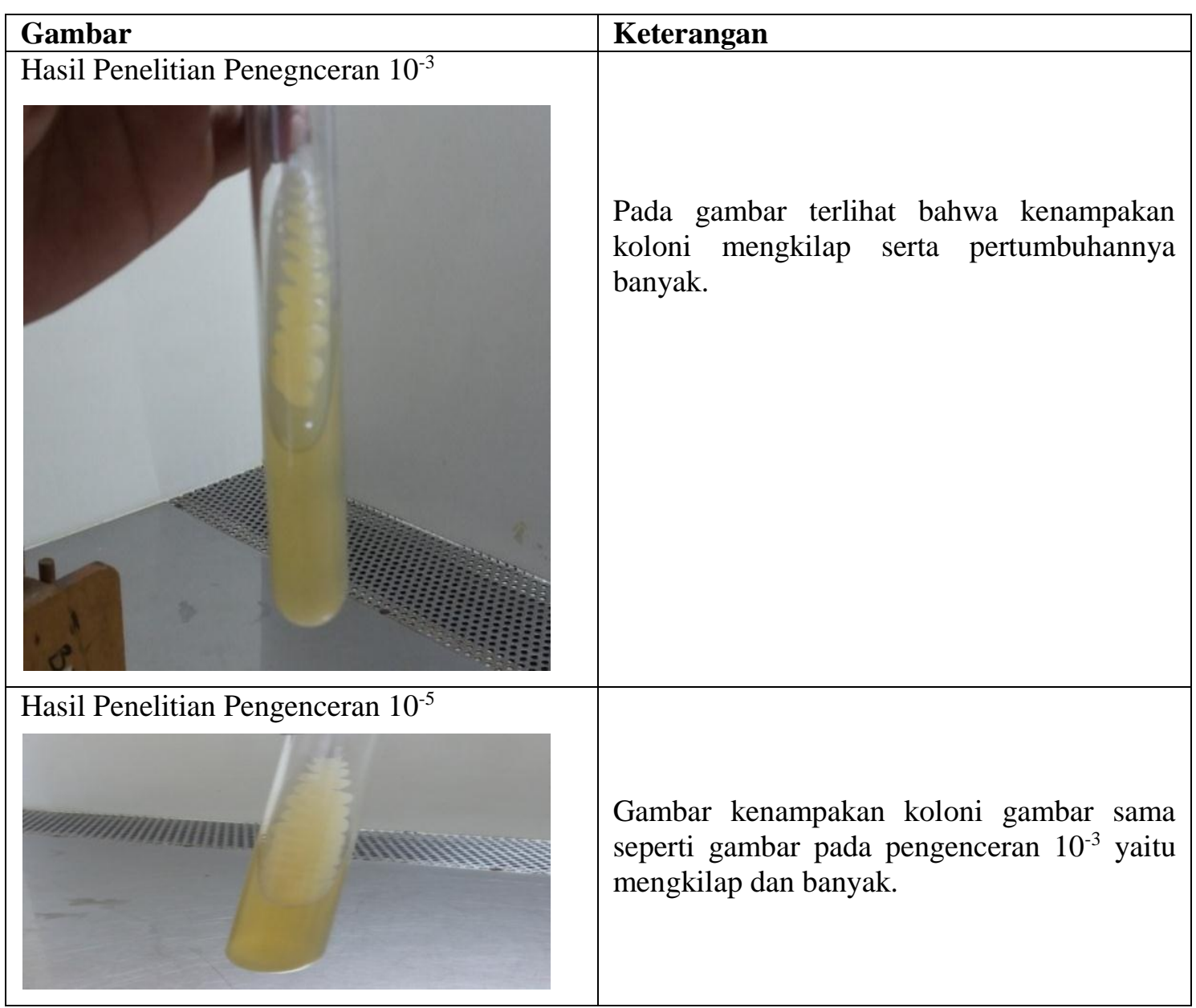

Tabel 4. Hasil Pengecatan Gram

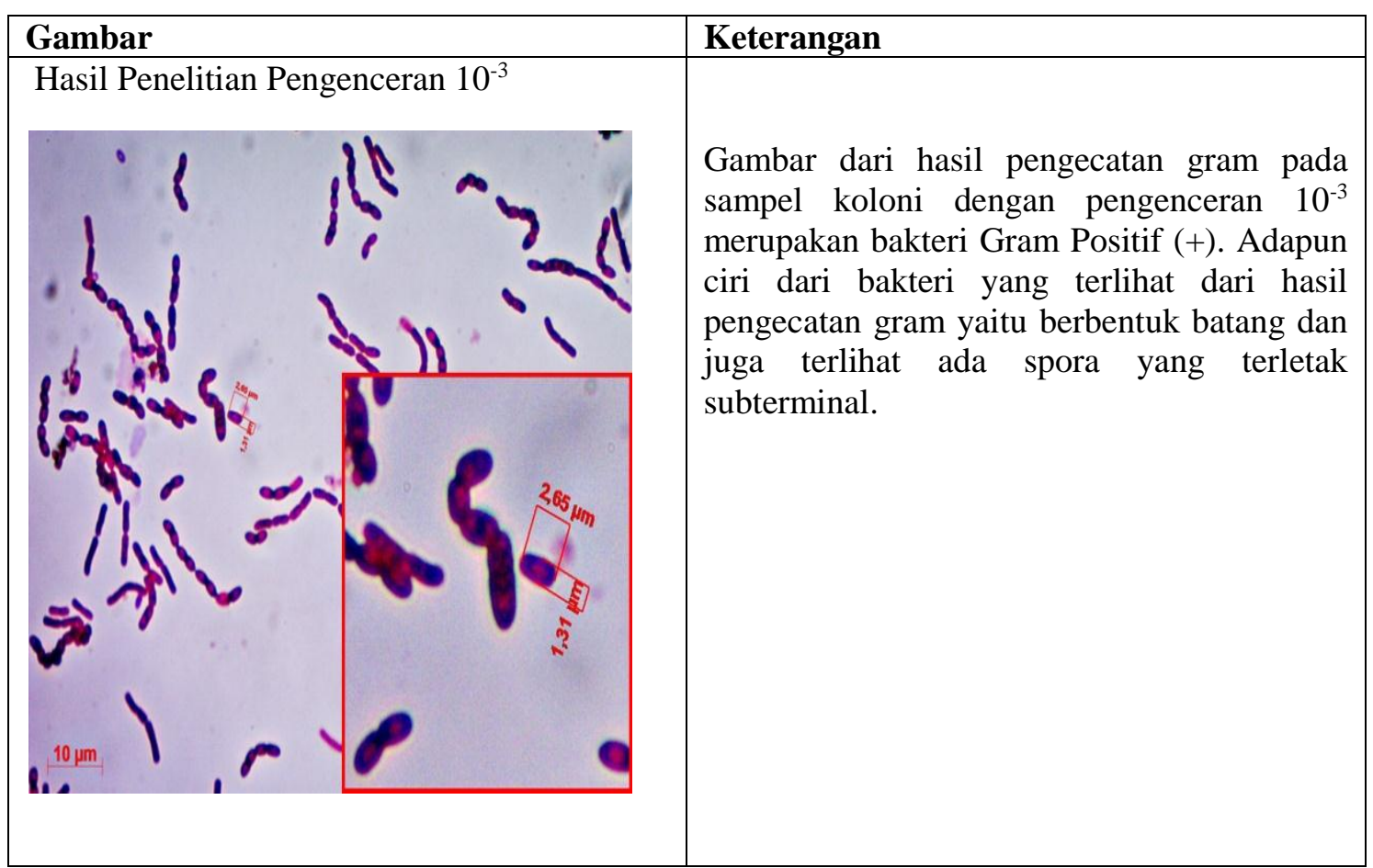




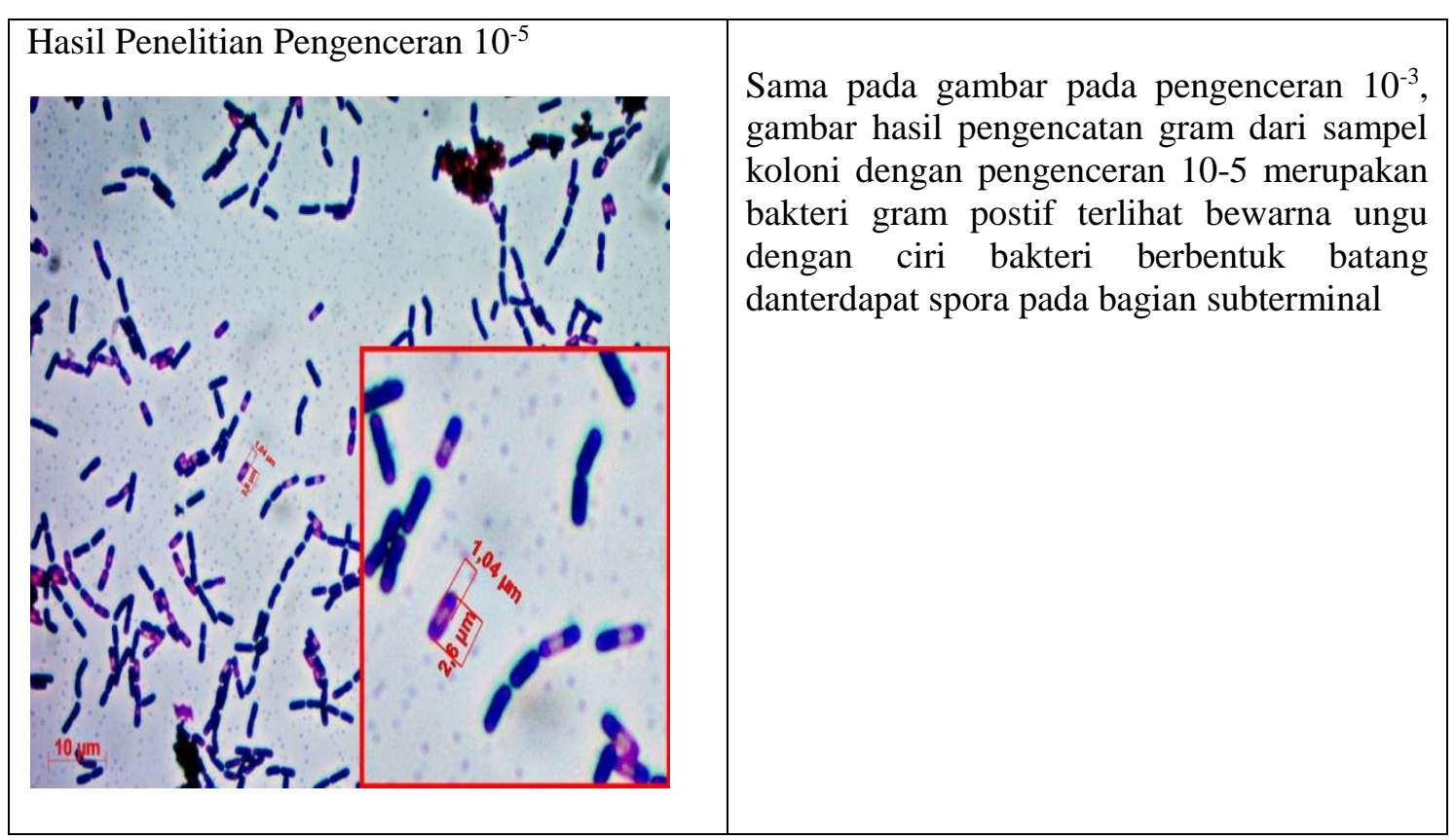

Tabel 5. Hasil Pengecatan Spora

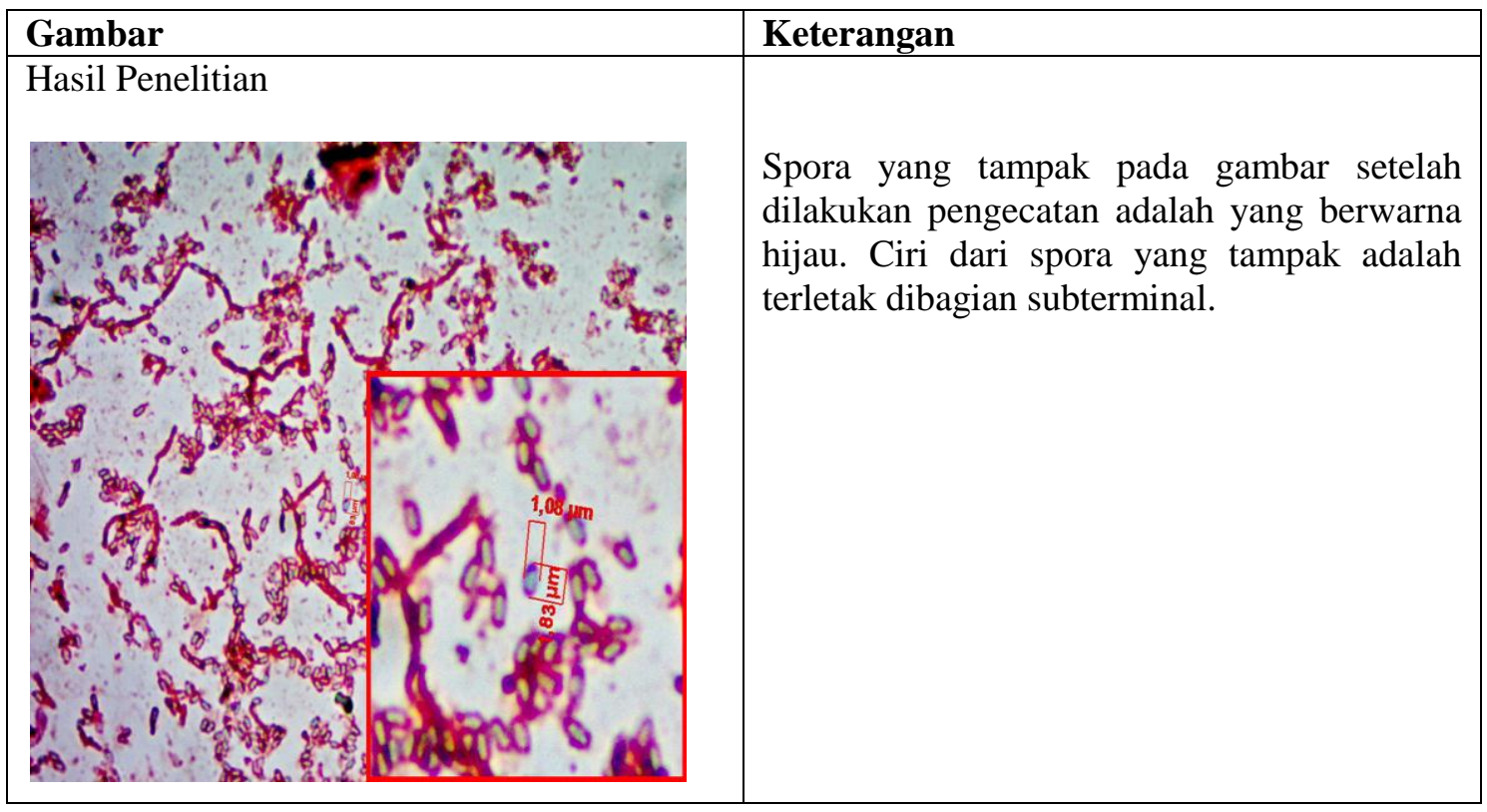

Hasil uji toksisitas isolat Bacillus thuringiensis murni yang dicampurkan dengan medium lalat buah pada konsentrasi $0,5 \mathrm{~g} / \mathrm{L}, 1$ $\mathrm{g} / \mathrm{L}, 2 \mathrm{~g} / \mathrm{L}$, dan $4 \mathrm{~g} / \mathrm{L}$ tidak menunjukkan efek toksik pada imago Drosophila melanogaster hingga hari ke 15 pengamatan. Penelitian ini bertujuan untuk mengisolasi, memurnikan, dan menguji toksisitas bakteri Bacillus thuringiensis dari tanah kandang sapi terhadap lalat buah. Untuk mengidentifikasi setiap mikroorganisme yang ada diperlukan teknik isolasi. Pada penelitian kali ini, sampel yang digunakan untuk mengisolasi bakteri adalah tanah kandang sapi yang berada di daerah Sandik, Lombok Barat.
Tekstur tanah cukup padat dan lembab sehingga memungkinkan untuk tumbuh bakteri Bacillus thuringiensis mengingat habitat alami dari bakteri Bacillus thuringiensis adalah pada tanah. Perlakukan pertama adalah menimbang sampel sebanyak 10 gram tanah kemudian dicampur dengan $90 \mathrm{ml}$ aquadest dan di vortex hingga homogen. Setelah itu dipanaskan pada waterbath pada suhu $80^{\circ} \mathrm{C}$ selama 5 menit. Fungsi pemanasan adalah untuk menghilangkan bakteri lain selain Bacillus thuringiensis yang tidak mampu hidup pada suhu $80^{\circ} \mathrm{C}$. Pengaruh suhu sangat penting bagi bakteri Bacillus thuringiensis. Setiap strain bakteri memiliki 
rentang suhu pertumbuhan yang berbeda-beda sehingga suhu lingkungan menjadi salah satu faktor yang sangat penting menentukan kecepatan pertumbuhan bakteri. Bila berada di luar rentang suhu pertumbuhannya, akan berakibat pada melambatnya kecepatan pertumbuhan strain bakteri tersebut. Fenomena ini terkait dengan kinerja enzim. Ketika bakteri tersebut masih berada rentang suhu lingkungannya maka peningkatan suhu akan diikuti dengan kecepatan pertumbuhan. Suhu lingkungan yang lebih tinggi dari rentang suhu pertumbuhan akan menyebabkan denaturasi protein enzim yang berakibat pada turunnya kinerj enzim yang berdampak pada melambatnya pertumbuhan bakteri.

Berdasarkan rentang suhunya, mikroba dikelompokkan kedalam 3 kelompok yaitu mikroba psikrofil, mikroba mesofil, dan mikroba termofil. Bakteri Bacillus thuringiensis termasuk dalam kategori termofilik, dengan rentang suhu pertumbuhan $40^{\circ} \mathrm{C}-75^{\circ} \mathrm{C}$ dengan suhu optimum $55^{\circ} \mathrm{C}-60^{\circ} \mathrm{C}$ (Hidayat, 2006). Suhu lingkungan maksimum Bacillus thuringiensis untuk dapat hidup hanya sampai $55^{\circ} \mathrm{C}-60^{\circ} \mathrm{C}$, namun karena memiliki kemampuan membentuk endospora dalam lingkungan ekstrim, maka bakteri Bacillus thuringiensis mampu bertahan pada suhu tinggi. Setelah sampel tanah yang telah diencerkan dengan aquadest dipanaskan, selanjutnya dibuat seri pengenceran dengan konsentrasi $10^{-1}-10^{-5}$. Tujuan dari pembuatan seri pengenceran adalah utuk mengurangi kepadatan jumlah bakteri yang akan diisolasi sehingga tidak terjadi spreader dan morfologi koloni bakteri dapat teramati dengan mudah. Setelah itu dilanjutkan dengan menginokulasi bakteri dari seri pengenceran ke dalam media NA yang mengandung nutrisi agar bakteri dapat tumbuh dengan optimal. Menurut Priadie, et al (2004) bahwa jenis media yang digunakan tergantung tujuan yang ingin dicapai. Hampir semua jenis medium kultur dapat ditumbuhi dengan baik oleh sejumlah spesies bakteri. Meskipun demikian beberapa spesies bakteri yang lain justru memerlukan medium kultur yang diperkaya dengan tambahan suplemen tertentu (Benson, 2001).

Pada penelitian yang dilakukan, bakteri Bacillus thuringiensis diinokulasikan menggunakan teknik pour plate, dan diinkubasi selama 1 hari pada suhu $28^{\circ} \mathrm{C}$. Tujuan inkubasi adalah untuk mengoptimalkan pertumbuhan Bacillus thuringiensis sehingga morfologi koloni dapat diamati dengan jelas. Hasil pengamatan yang dilakukan setelah proses inkubasi selama 1 hari adalah terdapat koloni yang berbentuk circular, warna putih kekuningan dan kenampakan permukaan koloni sedikit kasar dan mengkilap (Tabel 1). Hasil yang ada menunjukkan bahwa ciri-ciri yang ditunjukkan adalah merupakan ciri-ciri Bacillus thuringiensis (Zeigler, 1999). Hasil koloni yang didapatkan pada media NA masih sangat padat dan menumpuk sehingga perlu dikultur untuk mendapatkan hasil yang lebih baik. Untuk lebih memastikan apakah koloni yang didapatkan pada media NA merupakan Bacillus thuringensis, maka diambil satu ose koloni yang ada pada media NA dan dimasukkan ke dalam larutan LB dapar asetat $10 \mathrm{ml}$ dengan $\mathrm{pH} \mathrm{6,8.}$

Derajat keasaman medium $(\mathrm{pH})$ turut berperan penting dalam menentukan pertumbuhan bakteri (Kataren, 1990). Perubahan pH medium jamak terjadi saat mikroba sedang bertumbuh. Perubahan $\mathrm{pH}$ tersebut bisa disebabkan oleh terbrntuknya ion amonium terkait dengan metabolisme protein atau asam amino. Pada mikroba tanah perubahan $\mathrm{pH}$ ini dapat menghentikan metabolism mikroba yang bersangkutan (Lay, 1994). Benhard dan Utz (1993) menyatakan bahwa Bacillus thuringiensis dapat tumbuh pada medium yang memiliki $\mathrm{pH}$ pada kisaran 5.5 - 8.5 dan tumbuh optimum pada pH 6.5 - 7.5. Media LB dapar asetat dengan $\mathrm{pH}$ 6.8 yang digunakan merupakan media dengan $\mathrm{pH}$ optimum sehingga larutan ini merupakan media selektif dari Bacillus thuringiensis. Menurut Yusilman (2014) bahwa media selektif adalah media yang mampu menumbuhkan bakteri tertentu dan menghambat pertumbuhan bakteri lain (bakteri non target). Sehingga bakteri yang dapat hidup pada media selektif yang digunakan adalah bakteri Bacillus thuringiensis.

Setelah koloni tunggal dipindahkan kedalam media selektif, selanjutnya diinkubasi dengan cara digoyangkan pada kecepatan 150 rpm selama 1 hari. Setelah satu hari, terlihat hasil koloni berada di dasar tabung dan selanjutnya dipanaskan pada suhu $80^{\circ} \mathrm{C}$ selama 5 menit dan setelah itu divoetx agar homogen. Pemanasan dilakukan agar bakteri lain selain Bacillus thuringiensis tidak dapat hidup atau mati. Kemudian dilakukan penegenceran $10^{-1}-10^{5}$ agar mendaptkan hasil koloni yang bagus dan tidak terlalu padat dan selanjutnya ditumbuhkan ke media NA yang ditambah dengan lartan LB dapar asetat. Setelah itu diinkubasi selama 1 hari untuk melihat koloni yang tumbuh. Berdasarkan hasil inkubasi selama 1 hari didapatkan bahwa pada pengnceran $10^{-3}$ dan $10^{-5}$ terdapat koloni 
yang tidak terlalu padat sehingga dapat teramati dengan baik. Berdsarkan hasil pengamatan didaptkan bahwa koloni pada media tumbuh merupakan koloni dari Bacillus thuringiensis dengan ciri-ciri yaitu bentuk circular berwarna putih kekuningan, kenampakan dari koloni mengkilap dan sedikit kasar (Zeigler, 1999). Hasil koloni yang didapkan dapat terlihat pada tabel 4.2. Selanjutnya diambil satu ose koloni yang ada kemudian distreak pada media LB agar miring setelah itu diinkubasi selama 1 hari. Hasil yang didapatkan yaitu kenampakan koloni mengkilap dengan pertumbuhan yang banyak (Tabel 3).

Berdasarkan hasil pengamatan koloni, selanjutnya dilakukan pengecatan gram. Bakteri dapat dikelompokkan ke dalam kelompok gram positif atau kelompok gram negatif dengan teknik pewarnaan Gram (Waluyo, 2010). Dari hasil pewarnaan Gram yang telah dilakukan, sampel pada pengenceran $10^{-3}$ dan $10^{-5}$ merupakan bakteri gram positif. Pewarnaan Gram pada Bacillus thuringiensis yang telah dilakukan pada penelitian ini seperti yang disajikan pada table 4, berwarnaan keunguan dan berbetuk basil. Hal ini sesuai dengan literatur yang mengatakan bahwa Bacillus thuringiensis merupakan bakteri gram positif dan berbentuk basil dan dapat pembentukan spora (Hatmanti, 2000). Peptidoglikan, asam teikuronat serta asam teikoat yang terkandung dalam dinding sel bakteri Gram positif lah yang menentukan warna yang muncul pada bakteri golongan ini (Klien, et al., 2007).

Selain pengecatan gram, pengecatan spora juga dilakukan untuk melihat adanya spora pada bakteri Bacillus thuringiensis. Hasil dari uji pewarnaan spora dapat terlihat dengan jelas pada Tabel 5 yaitu adanya spora yang terbentuk didalam sel berwarna hijau yang meneyarap larutan malachit green. Untuk mengamati spora dibuthkan pewarna yang mampu menembus dinding spora yang tebal. Malachit green adalah salah satu jenis pewarna yang mampu menembus dinding spora bakteri. Untuk memperjelas pengamatan, sel vegetatif juga diwarnai dengan larutan safranin sehingga sel vegetatif bewarna merah. Dengan demikian ada atau tidaknya spora dapat teramati bahkan posisi spora dalam tubuh sel vegetatif juga dapat diidentifikasi. Asam duplikonat adalah senyawa khas yang selalu terkandung dalam semua spora bakteri. Senyawa ini hanya bisa diwarnai oleh pewarna tertentu, seperti malachite green (Volk \& Wheeler, 1988).
Pada penelitian ini ukuran spora yang ada yaitu $1,83 \mu \mathrm{m}$ dengan bentuk spora bulat memanjang dan terletak subterminal. Berbeda dengan jamur dan tumbuhan paku, spora bakteri tidak berperan dalam perkembangbiakan. Tipe spora pada bakteri bisa berupa endospora karena terbentuk di dalam sel, atau berupa eksospora karena terletak di luar sel. Bentuk spora juga bisa bervariasi, tergantung spesies bakterinya. Bentuknya bisa bulat atau bulat panjang (Waluyo, 2007). Diameter endospora bisa berukuran lebih besar atau lebih kecil dibandingkan dengan diameter sel induknya. Spora bakteri sebagian besar ditemukan pada bakteri tanah. Ukuran spora bisa berbeda pada spesies bakteri yang berbeda. Letaknya pun bisa bervariasi, di bagian tengah sel (sentral), di ujung sel (terminal), atau di dekat ujung sel (sub terminal). Identifikasi bakteri ikut ditentukan oleh ukuran dan letak spora tersebut (Pelczar \& Chan, 1986). Pada awalnya bakteri penghasil endospora masih terbagi ke dalam 2 golongan yaitu genus Clostridium termasuk dalam golongan gram negatif, dan Bacillus yang termasuk ke dalam golongan gram positif. Setelah itu bakteri penghasil endospora kemudian dikelompokkan ke dalam 6 genus yaitu Bacillus, Sporolactobacillus, Clostridium, Desulfotomaculum, Sporosarcina, dan Thermoactinomycetes (Hatmanti, 2000).

Kemampuan Bacillus thuringiensis bertahan hidup hingga beberapa generasi dalam kondisi yang ekstrim disebabkan oleh kemampuannya membentuk spora. Spora tersebut terbentuk melalui sintesis protoplasma baru di dalam sitoplasma sel vegetatifnya (Pelczar, 1986). Tahapan pembeetukan spora bakteri atau sporulasi terbagi ke dalam tujuh tahap. Proses ini diawali dengan terhentinya proses penggandaan DNA dan diakhiri dengan penghancuran dinding sel secara enzimatis untuk membebaskan spora (Ray, 2004). Hasil uji toksisitas isolat Bacillus thuringiensis murni yang dicampurkan dengan medium lalat buah pada konsentrasi 0,5 g/L, $1 \mathrm{~g} / \mathrm{L}, 2 \mathrm{~g} / \mathrm{L}$, dan $4 \mathrm{~g} / \mathrm{L}$ tidak menunjukkan efek toksik pada imago Drosophila melanogaster hingga hari ke 15 pengamatan. Hal tersebut menunjukkan bahwa imago Drosophila melanogaster bukan merupakan spesies target isolat Bacillus yang diperoleh.

\section{Kesimpulan}

Berdasarkan tujuan dari penelitian ini, maka kami dapat menyimpulkan yaitu sebagai 
berikut: 1). Bacillus thuringiensis berhasil diisolasi dari tanah daerah kandang dengan menggugnakan media selektif Luria Bertani (LB) yang mengandung larutan dapar asetat $0,25 \mathrm{M}$ dengan $\mathrm{pH}$ 6,8. 2). Isolat Bacillus thuringiensis yang diperoleh menunjukkan karakteristik dari bakteri gram-positif dan memiliki spora yang terletak pada bagian subterminal. 3). Isolat Bacillus thuringiensis murni yang dicampurkan dengan medium lalat buah pada konsentrasi 0,5 $\mathrm{g} / \mathrm{L}, 1 \mathrm{~g} / \mathrm{L}, 2 \mathrm{~g} / \mathrm{L}$, dan $4 \mathrm{~g} / \mathrm{L}$ tidak menunjukkan efek toksik pada imago Drosophila melanogaster hingga hari ke 15 pengamatan.

\section{Ucapan Terima Kasih}

Terima kasih kami sampaikan kepada semua pihak yang telah membantu pelaksanaan kegiatan Penelitian ini. Ucapan terima kasih juga ditujukan kepada Bapak Rektor Universitas Mataram, Ketua Lembaga Pengabdian kepada masyarakat Universitas Mataram dan Dekan FKIP Universitas Mataram.

\section{Referensi}

Bravo, A., S. Sarabia, L. Lopez, H. Ontiveros, C. Abarca, A. Ortiz, L.Lina, F.J. Villalobus, G. Pena, M. Nunez-Valdez, M. Soberon, \& R. Quintero. (1998). Characterization of cry genes in a Mexican Bacillus thuringiensis strain collection. Appl.Environ. Microbiol. 64(12): 49654972

Brotonegoro, S., Sutrisno., Sugiarto, B., Listanto, B., \& Santoso. (1997). Perbaikan Sifat Beberapa Isolat Bacillus thuringiensis untuk Mendukung pemanfaatannya sebagai Insektisida Mikroba. Laporan Hasil Penelitian APBN. Balai Penelitian Bioteknologi Tanaman Pangan Bogor.

Copeland RS., RA. Wharton, Q. Luke, MD. Meyer, S. Lux, N. Zenz, P. Machera and M. Okumu (2006). Geographic Distribution, Host Fruit, and Parasitoids of African Fruit Fly Pest Ceratitis anonae, Ceratitis cosyra, Ceratitis fasciventris, and Ceratitis rosa (Diptera: Tephritidae) in Kenya. Ann. Entomol. Soc. Am.99(2) : 261-278 (2006).

Crickmore N., DR. Zeigler., J. Feitelson., E. Schnep., J Van Rie., D. Lerectus., J.
Baum., DH. Dean. 1998. Bacillus thuringiensis toxin nomenclature. Microbiology and Molecular Biology Reviews, 62: 807813

Deptan (2002). Panduan Lalat Buah. http://www.deptan.go.id/ditlinhorti/makal ah/lalat_buah.htm. Diakses 13 September 2005.

Hayes TB., P. Case., S. Chui., D. Chung., C. Haeffele., \& K. Haston. (2006). Pesticide mixtures, endocrine disruption, and amphibian declines: are we underestimating the impact? Environ Health Perspect, 114: 40-50

Holt, J.G., Krieg, N.R., Sneat, PHA, Stanley, J.T, \& William, S.T. (1994). Bergey's Manual of Determinative Bacteriology. Maryland USA, Wlliam \& Wilkins.

Hammanti, A. (2000). Pengenalan Bacillus sp. Puslitbang Oseanologi LIPI, Jakarta

Mummigati \& Raghunatan (1990). Influence of Media Composition on the Production of Delta-endotoxin by Bacillus thuringiensis var israeliensis. J. Intervertebr. Pathol, 55: $147-155$

Pigott (2008). Ciri-Ciri Bacillus thuringiensis (Bt). http://digilib. unila.ac.id/1943/ 7BAB\%2011.pdf. Diakses pada 29 Oktober 2015

Schnep. E., N. Crickmore., J. Van Rie., D. Lerectus., J. Baum., J. Feitelson., DR. Zeigler., \& DH. Dean (1998). Bacillus thuringienss and it's pesticidal crystal protein. Microbiology and Molecular Biology Reviews, 62 (3); 775-806

Siwi SS., P. Hidayat, \& Suputa (2006). Taksonomi dan Bioekologi Lalat Buah Penting, Bactrocera spp. (Diptera : Tephritidae) di Indonesia. Balai Besar Penelitian dan Pengembangan Bioteknologi dan Sumberdaya Genetik, Bogor

Suwanda (2005). Karantina Pertanian Negara Kepulauan. Sosialisasi Karantina, Cirebon 29 Nopember 2005. 
Swadener, C. (1994). Bacillus thuringiensis. Journal of Pesticides Reform, 14(3): 13 20. Northwest Coalition for Alternative to Pesticides. Ottawa

Vargas RI., JD. Stark, B. Mackey and R. Bull. (2005). Weathering Trials of Amulet CueLure and Amulet Methyl Eugenol "Attract-and-Kill" Stations with Male Melon Flies and Oriental Fruit Flies (Diptera:tephritidae) in Hawai. J. Econ. Entomol. 98(5): 1551-1559 (2005).

Wei JZ., K. Hale., L. Carta., E. Platzer., C. Wong., SC. Fang., \& RV. Aroian (2003). Bacillus thuringiensis crustal protein that target nematodes. Proceedings of the National Academy of Sciences of the United States of America. 100(5): 27602765
White IM and MM Elson-Harris (1992). Fruit Flies of Economic Significance : TheirIdentification and Bionomics. CABI and ACIAR, UK.

World Health Organization (1990). Public Health Impact of Pesticides Used in Agriculture. England: World Health Organization

Zeigler, D.R. (1999). Bacillus Genetic Stock Center of Strains, Part 2: Bacillus thuringiensis and Bacillus cereus. The Ohio University. Ohio.

Zheng S., B. Chen B., X. Qiu., M. Chen., Z. Ma., \& X. Yu (2016). Distribution and risk a ssessment of 82 pesticides in Jiulong River and estuary. Chemosphere, 144: 1177 1192 